\title{
FANCG Gene Mutation
}

National Cancer Institute

\section{Source}

National Cancer Institute. FANCG Gene Mutation. NCI Thesaurus. Code C156016.

A change in the nucleotide sequence of the FANCG gene. 